\title{
Making Bioetanol from Glucose Off Grade With Fermentation Process Using Fermiol
}

\author{
Ni Ketut Sari ${ }^{1 *}$, Khurniawati ${ }^{2}$, Moh. Uman Fathoni ${ }^{3}$, Widi Wurjani ${ }^{4}$ \\ ${ }^{1,3}$ Department of Chemical Engineering \\ ${ }^{2,4}$ Department of Agriculture \\ Universitas Pembangunan Nasional "Veteran" Jawa Timur \\ Surabaya, Indonesia \\ *ketutsari.tk@upnjatim.ac.id
}

\begin{abstract}
Fermentation can be defined as a process of anaerobic oxidation of carbohydrate which produces alcohol and carbon dioxide. Batch fermentation is fermentation system closed, where there is no addition of new media, there are no additions (O2), antifoam, acid/alkaline $\mathrm{pH}$ control is done in a way. the fermentation process using Saccharomyces cerevisiae producing optimum conditions on the addition of the Saccharomyces cerevisiae of $7 \%(\mathrm{v} / \mathrm{v})$ and the time of fermentation produces ethanol for 10 days of $20.88 \%$ and a residual sugar of $2.44 \%$. Use of microbial Nopkor Mz. held on the addition of the sugar with the levels of $15 \%(b / v)$ and time for 8 days of fermentation produces alcohol levels of $9.3 \%$. From the research that has been done, the process of fermentation can take place using Microbe Saccharomyces Cerevisiae, $K$. Marxianus, Nopkor Mz, and Zymomonas Mobilis, Mz CP4. This research has been conducted on the analysis focusing on the purpose to find out the optimum time and glucose concentration, with a fermentation process for 7 days using glucose off grade and fermiol as well as urea and NPK nutrients as microorganisms. After dilution it is known that the content of glucose in glucose off grade raw materials amounting to $80 \%$. From the results of this process of dilution is done according the levels of variables being run, then fermented for 7 days using fermiol. The best results on the fermentation of glucose levels at $14 \%$ and lasted for 6 days that generate levels of bioethanol of $11 \%(\mathrm{v} / \mathrm{v})$ with the highest percentage yield of $61.63 \%$.
\end{abstract}

Keywords-bioethanol; glucose; fermiol

\section{INTRODUCTION}

Ethanol or ethyl alcohol is fermented product that can be manufactured from substrates containing carbohydrates. In the world of industrial ethanol is used as blends for beverages like sake or gin, pharmaceutical and cosmetic raw materials, fuel and a mixture of vehicles, fuel ethanol (gasohol) and as a source of oxygen for combustion cleaner substitute (methyl tertiary-butyl ether MTBE/). Because ethanol contains 35\% oxygen, can increase the efficiency of combustion. Ethanol is also environmentally friendly because of the low levels of excess gas emissions of carbon monoxide, nitrogen oxides, and greenhouse gases that become pollutants so as not to pollute the environment [1].

Bioethanol can be produced from a few raw materials, i.e. the sugared ingredients, starch, and lignocellulose. One of the materials that can be utilized to become sugared raw material in the manufacture of bioethanol is glucose off grade. Off grade glucose itself is not yet certified the glucose Standard National Indonesia (SNI). Glucose can be said to have fulfilled in a full grade LEVEL include, odorless, tasteless, colorless, sweet water content maximum $20 \% \mathrm{~b} / \mathrm{b}$, grey levels maximum $1 \% \mathrm{~b} / \mathrm{b}$, and reducing sugar levels at least $30 \% \mathrm{~b} / \mathrm{b}$. previous studies on the production of glucose from sago starch stated that one of the indicators of causes not yet certified sugar is a reddish yellow on the glucose that is caused by the presence of reducing sugars and protein in starch which led to occurrence of brownish, in addition total dissolved solids (TPT) expressed in ${ }^{\circ}$ Brix in the liquid sugar is still low i.e. by $60^{\circ}$ Brix so still there is moisture content in large numbers, and also typical flavored sugar glucose [2].

In the year 2010 needs glucose in Indonesia reached 21360 tons every year and has increased in the year 2011 to reach 29331 tons annually. This indicates that the need of glucose in Indonesia has increased every year [3]. Food and beverage industry currently has a tendency to use glucose syrup as raw sugar substitute. But most of the industry prefers to use glucose syrup which has been SNI standard as the raw material manufacture its products than on using glucose off grade thus causing a decline in selling prices of glucose off grade on the market [2]. It need to be made off of glucose have grade to grade off glucose selling power can be increased. One solution is to change the grade off glucose into products bioethanol using the fermentation process.

Fermentation can be defined as a process of anaerobic oxidation of carbohydrate which produces alcohol and carbon dioxide. Batch fermentation is fermentation system closed, where there is no addition of new media, there are no additions, antifoam, acid/alkaline $\mathrm{pH}$ control is done in a way. Batch fermentation are widely used in industry to produce ethanol because of the ease of sterilization process and control tools [4]. But there are some disadvantages of 
batch fermentation, i.e., barriers due to the high sugar levels, the concentration of the ethanol yield limited (12\%) and productivity levels because the ethanol produced is low, due to the accumulation of ethanol, formed by the fermenters will poison the microorganism who was instrumental in the formation of ethanol itself, so that the growth and production of microorganism can be stopped [5]. Despite this batch fermenting still an option because the yield obtained is higher than with other methods [4].

Previous research for the optimization of fermentation process using Saccharomyces cerevisiae producing optimum conditions on the addition of the Saccharomyces cerevisiae of $7 \%(\mathrm{v} / \mathrm{v})$ and the time of fermentation produces ethanol for 10 days of $20.88 \%$ and the rest of the sugar of $2.44 \%$. Optimum conditions of making wine from apples rejects using microbial Nopkor Mz. held on the addition of the sugar with the levels of $15 \%(\mathrm{~b} / \mathrm{v})$ and time for 8 days of fermentation produces alcohol levels of $9.3 \%$ [1]. Other studies on the production of ethanol from molasses optimum conditions in Borassus flabel lifer fermentation using Saccharomyces cerevisiae bacteria i.e. at $\mathrm{pH} 4.8$, the concentration of sugar is $110 \mathrm{~g} / \mathrm{L}$, a concentration inoculum $12,740,970$ cells/ml and obtained yield ethanol $23.68 \%$ (y/y) [4]. Ethanol can also be retrieved from jackfruit seeds fermented using Saccharomyces cerevisiae grams 0.03, 0.1 grams of urea 0.05 grams NPK for 6 days generate levels of $13 \%$ ethanol \%(v/v) [6]. According to [7] in the production of tuber bioethanol Ube using Saccharomyces cerevisiae, optimum conditions are held on with the addition of $1.5 \%$ of the yeast and nutrients from 0.1 grams $/ 100 \mathrm{ml}$ of urea and NPK $0.1 \mathrm{~g} / 100 \mathrm{ml}$ and the time of fermentation for 12 days 9.97 bioethanol levels obtained\% (v/v).

Optimum conditions for fermentation of ethanol from $30^{\circ} \mathrm{C}$ temperatures occur in the mangrove, the stirring speed $360 \mathrm{rpm}$ and fermentation lasted 89 minutes produce ethanol with a yield maximum $69.58 \%$ [8]. Other studies mention that the optimum fermentation conditions of sugar cane by using bagas Zymomonas mobilis CP4 obtained at concentrations of inoculum urea concentration of $15 \%, 0.3 \%$, long fermentation 45 hours and the resulting optimum 1.257 ethanol \% (v/v) [9]. Conditions optimum for the fermentation of ethanol from mango upgrade using microba K. Marxianus is at a concentration of glucose $20{ }^{0} \mathrm{Brix}, \mathrm{pH} 4.6$ for 12 days, gained a $5 \%$ ethanol (b/v) [10].

From the research that has been done, the process of fermentation can take place using Microbe Saccharomyces cerevisiae, K. Marxianus, Nopkor and Zymomonas mobilis, $\mathrm{Mz} \mathrm{CP4}$. On the research we do focused knowing the concentration of glucose and the optimum time, with fermentation for 7 days using glucose off grade and Fermiol as well as urea and NPK nutrients as microorganisms. On the fermentation of glucose off grade be bioethanol for 7 th day use fermiol $0.15 \mathrm{~g} / \mathrm{L}$ urea and NPK, as much as $0.1 \mathrm{~g} / 100 \mathrm{ml}$ as the nutrient levels of the highest bioethanol, allegedly resulting in glucose levels of $14 \%$ on the sixth day.

\section{THE PROCESS BIOETHANOL}

\section{A. Glucose Off Grade}

One of the materials that can be utilized to become sugared raw material in the manufacture of bioethanol is glucose off grade. This grade is off glucose has not certified the Standard National Indonesia (SNI) so it has a low price, in contrast to the price of the glucose has standard SNI which is still expensive in the market. In fact the need for glucose syrup is still high but this high requirement has yet to be fulfilled so do imports of sugar as an alternative. Glucose syrup is usually used as an additional ingredient in the manufacture of soy sauce, syrup, candy, and others [2].

TABle I. The QuAlity of THE Molten Sugar Best TREATMENT

\begin{tabular}{|l|l|l|}
\hline \multicolumn{1}{|c|}{ Parameters } & \multicolumn{1}{|c|}{ Unit } & \multicolumn{1}{c|}{ SNI } \\
\hline The smell of & - & Odorless \\
A sense of & - & Sweet \\
Color & - & Colorless \\
Water & $\% \mathrm{~b} / \mathrm{b}$ & A maximum of 20 \\
Abu & $\% \mathrm{~b} / \mathrm{b}$ & A maximum of 1 \\
Reducing sugar calculated as & $\% \mathrm{~b} / \mathrm{b}$ & At least 30 \\
D-glucose metal Impurities: & & \\
Lead $(\mathrm{Pb})$ & $\mathrm{ppm}$ & Maximum 1 \\
Copper $(\mathrm{Cu})$ & $\mathrm{ppm}$ & Maximum 10 \\
Zinc (Zn) & $\mathrm{ppm}$ & Maximum 25 \\
Arsenic (As) & $\mathrm{ppm}$ & Maximum 0.5 \\
Microbial Impurities: & & \\
Plate Number & colony/g & Maximum 5x102 \\
Total Mold & colony /g & Maximum 50 \\
Yeasts & colony /g & Maximum 50 \\
\hline
\end{tabular}

(Source: [2])

\section{B. Fermentation process}

The process of converting glucose generally require anaerobic conditions for maximizing the manufacture of ethanol [11]. Yeast used in the fermentation of alcohol which results primarily ethanol [12]. Anaerobic conditions, microbes that can be used is a Saccharomyces Cerevisiae [13]. Saccharomyces cerevisiae is a yeast which is important in the manufacture of alcoholic beverages like beer, wine, and is also used in making bread dough [12]. Saccharomyces Cerevisiae is a Microbe that is best for the fermentation of ethanol because it is relatively more efficiently convert the sugar into ethanol and more tolerant of ethanol [13]. In addition to Saccharomyces Cerevisiae and Zymomonas Mobilis is also very potential. However, these bacteria need to be developed further, due to a low against the toleration of salt in the media and in need of a sterile medium, so that makes it difficult for industrial-scale application [14].

Microorganism Saccharomyces Cerevisiae can be obtained from fermiol, red star, Baker's yeast, all tech, and gert strand. Based on the research results with the test conditions are some of the highest temperatures are obtained by successive ethanol yield is red star, fermiol, gert strand, Baker's yeast, and all tech [15]. 
The advantages the use of fermiol Strain No. 7221 DY: Reduce the addition of yeast, generate little or no foam, reduce glycerol, can the fermentation takes place at higher temperatures, without the risk of stuck fermentation, result of higher alcohols in the absence of a barrier [17], short adaptation Phase, low acid production [16].

\section{Bioethanol Product}

The ethanol used in the drink obtained from the brewing of carbohydrates catalyst enzymes. One type of enzyme changing carbohydrates into glucose, then into ethanol, the type of the other produce vinegar acid with ethanol as an intermediate. Source of carbohydrates for brewing relies on the availability of the purpose of the use of alcohol. Brewing of fruits, vegetables or whole grains stops when the alcohol levels had reached $14-16 \%$. If a higher rate is desired, the mixture had to be distilled. Distillate (distilled) azeotrope is a mixture of $95 \%$ alcohol $5 \%$. An azeotrope is a mixture boils at a constant boiling point, as if it's a pure compound). This distillate can be blended back into the mix of brewing to increase the levels of ethanol, or can be added to water to get the desired levels (Fessenden, 1982). Bioethanol has a higher oxygen content which is around $35 \%$ which helps more perfect combustion and environment-friendly because it contains gas emissions lower CO [11].

TABLE II. EXPERIMENTAL RESULTS OF VARIOUS ETHANOL-PRODUCING YEAST

\begin{tabular}{|l|l|l|l|l|}
\hline & $\begin{array}{c}\text { Residual } \\
\text { Sugar }\end{array}$ & $\begin{array}{c}\text { Total Sugar } \\
\text { \% v/v }\end{array}$ & $\begin{array}{c}\text { Ethanol } \\
\text { \% v/v }\end{array}$ & $\begin{array}{c}\text { Yield } \\
\text { Ethanol }\end{array}$ \\
\hline Temperature $37.5^{\circ} \mathrm{C}$ & & & & \\
Fermiol & 9.33 & 37,84 & 13,73 & 62,16 \\
Alltech & 11.19 & 45,36 & 11,78 & 54,64 \\
Red Star & 8.44 & 34,23 & 14,34 & 65,77 \\
Gert Strand & 8.75 & 35,47 & 14,11 & 64,53 \\
Baker's Yeast & 11.38 & 46,13 & 11,88 & 53,87 \\
\hline Pada suhu 35 C & & & & \\
Fermiol & 5,93 & 24,05 & 15,85 & 75,95 \\
Alltech & 9,54 & 38,68 & 13,48 & 61,32 \\
Red Star & 5,37 & 21,78 & 16,06 & 78,22 \\
Gert Strand & 6,88 & 27,89 & 15,08 & 72,11 \\
Baker's Yeast & 9,21 & 37,35 & 13,79 & 62,65 \\
\hline Temperature 32 ${ }^{\circ} \mathrm{C}$ & & & & \\
Fermiol & 4,85 & 19,65 & 17,03 & 80,35 \\
Alltech & 9,61 & 38,95 & 13,93 & 61,05 \\
Red Star & 4,23 & 17,15 & 17,10 & 82,85 \\
Gert Strand & 5,25 & 21,27 & 16,27 & 78,73 \\
Baker's Yeast & 8,99 & 36,46 & 14,27 & 63,54 \\
\hline
\end{tabular}

(Source: [15])

Bioethanol is ethanol made from biomass containing cellulose or starch component. Raw materials bioethanol can be obtained from various plants which produce sugars (such as sugar cane and molasses), flour/starch such as corn, sago, and tubers such as cassava [7].

\section{METhodology ReSEARCH}

Based on the results of the initial material analysis (glucose off grade) obtained the following data: level $80 \%$.

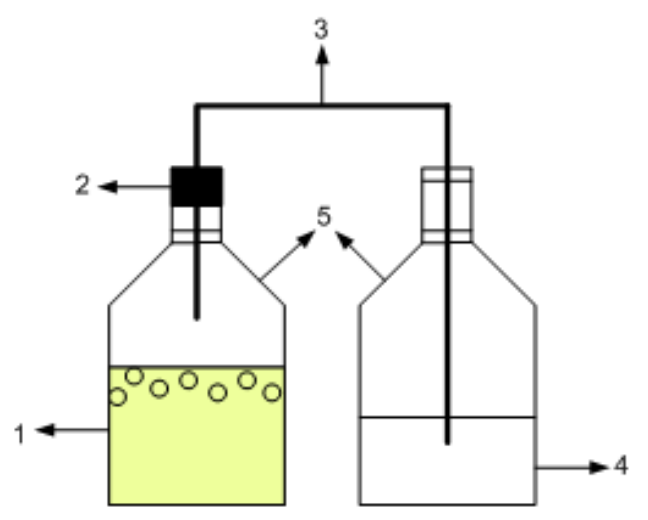

Image captions:

(1) Off grade of glucose; (2) Bottle Cover; (3) The connecting Hose; (4) Aquadest; (5) The bottle

Fig. 1. Making off grade glucose setting

Research procedure:

a. Prepare tools and materials as well as a series of fermenters were used.

b. Glucose off grade that has been analyzed then dissolved with aquadest up to $800 \mathrm{ml}$ with the appropriate concentration of the independent run.

c. Stir in the glucose solution into each bottle, and then sterile with autoclave for 15 minutes, chill $\pm 30^{\circ} \mathrm{C}$.

d. Then enter fermiol into the bottle containing a solution of glucose.

e. Add urea and NPK nutrients as microorganisms.

f. Close the bottle meetings lest there is the air into the bottle. Connect the hose to the presence of $\mathrm{CO}_{2}$ indicators 1 and 2 for the sampling interval.

g. Once the bottle tightly closed and all hoses are already set, the fermentation process is done accompanied by stirring speed $100 \mathrm{rpm}$ for 1 hour every day.

h. Analysis of the filtrate is fermented according the independent variable $(3,4,5,6,7)$ days.

\section{RESULTS AND DISCUSSION}

Based on chart Figure 1 can note that on day 3 to day 5 each increase the levels of alcohol except at $10 \%$ glucose levels which increase the levels of alcohol on the 4th day, constant on day 5 and decline alcohol levels on day 6. On the 7 th day of the samples with glucose levels by $10 \%$ and $18 \%$ experienced a decrease in the levels of alcohol. This condition indicates that the initial glucose levels that are too low and too high can affect the levels of alcohol produced. Where the levels of alcohol in the initial glucose levels that are too high and too low can cause the resulting alcohol levels will be low. 
Fermentation lasted 7 days with variable levels of glucose $10 \% ; 12 \% ; 14 \% ; 16 \%$; and $18 \%$ and obtained the following data:

TABLE III. THE LEVELS OF ETHANOL

\begin{tabular}{|c|c|c|c|c|c|}
\hline \multirow{2}{*}{$\begin{array}{c}\text { The Initial } \\
\text { Glucose Levels }\end{array}$} & \multicolumn{5}{|c|}{ Ethanol Levels (\%) } \\
\cline { 2 - 6 }$(\%)$ & 3 & 4 & 5 & 6 & 7 \\
\cline { 2 - 6 } & \multicolumn{5}{|c|}{ The Fermentation Time (Day) } \\
\hline 10 & 2 & 4 & 4 & 3 & 2 \\
\hline 12 & 5 & 6 & 7 & 8 & 8 \\
\hline 14 & 6 & 8 & 10 & 11 & 11 \\
\hline 16 & 6 & 7 & 8 & 10 & 10 \\
\hline 18 & 3 & 5 & 6 & 6 & 5 \\
\hline
\end{tabular}

After the fermentation process takes place in accordance with the variables being run, then obtained the best conditions to obtain the highest levels of ethanol. The best conditions in glucose levels $14 \%$ with the best fermentation time on the 6th day. To see the levels of glucose which can conversion then do analysis of glucose levels before and after fermentation the fermentation. As for the results of the analysis of the levels of glucose are as in table IV:

TABLE IV. THE LEVELS OF GLUCOSE

\begin{tabular}{|c|c|c|c|c|c|}
\hline \multirow{2}{*}{$\begin{array}{c}\text { The Initial } \\
\text { Glucose } \\
\text { Levels (\%) }\end{array}$} & \multicolumn{5}{|c|}{ The Remaining Glucose Levels (\%) } \\
\cline { 2 - 6 } & 3 & 4 & 5 & 6 & 7 \\
\hline 10 & 7.8 & 6.8 & 6.4 & 6.2 & 5.8 \\
\hline 12 & 7.4 & 6.6 & 5.4 & 4.6 & 4 \\
\hline 14 & 8.2 & 6.8 & 4.6 & 3.6 & 3.2 \\
\hline 16 & 11.4 & 10.2 & 8.8 & 6.6 & 6 \\
\hline 18 & 16.4 & 15.4 & 14 & 13.2 & 12.2 \\
\hline
\end{tabular}

Previous research for the fermentation process using Ube bulbs Saccharomyces cerevisiae producing optimum conditions on the addition of the Saccharomyces cerevisiae $1.5 \%(\mathrm{~b} / \mathrm{v})$ as well as the nutrients from $0.1 \mathrm{~g} / 100 \mathrm{ml}$ of urea and NPK $0.1 \mathrm{~g} / 100 \mathrm{ml}$ for 12 days 9.97 bioethanol levels obtained\% (v/v) [7]. Optimum conditions of making wine from apples rejects using microbial Nopkor Mz. held on the addition of the sugar with the levels of $15 \%(\mathrm{~b} / \mathrm{v})$ and time for 8 days of fermentation produces alcohol levels of $9.3 \%$ [1]. If compared with our study, bioethanol from glucose off grade have higher levels of ethanol that is $10 \%$ on the initial glucose levels $16 \%$, using fermiol $0.15 \mathrm{~g} /$ litre, the addition of urea and NPK $0.1 \mathrm{gr} / 100 \mathrm{ml}$, and long fermentation of 6 days. This is due to the use of fermiol that can produce higher alcohol levels of use of Saccharomyces Cerevisiae.

According to [1] to Saccharomyces Cerevisae used in fermenting wine, the alcohol-making using low initial sugar levels cause growth of yeast that short time resulting in low alcohol levels. This is because the number of microbes that form more when compared with the amount of food available at the beginning of fermentation.

TABLE V. YIELD AT OPTIMUM LEVELS OF ETHANOL

\begin{tabular}{|c|c|c|c|c|c|c|}
\hline $\begin{array}{c}\text { Glucose } \\
\text { Levels } \\
(\%)\end{array}$ & $\begin{array}{c}\text { Mas of } \\
\text { Glucos }) \\
\mathbf{e} \\
(\text { grams })\end{array}$ & $\begin{array}{c}\text { Levels } \\
\text { Ethano } \\
\mathbf{l} \\
(\% / v)\end{array}$ & $\begin{array}{c}\boldsymbol{\rho} \text { /v) } \\
\text { Ethanol } \\
(\mathbf{g} / \mathbf{m l})\end{array}$ & $\begin{array}{c}\text { Volume } \\
\text { Ethanol } \\
(\mathbf{m l})\end{array}$ & $\begin{array}{c}\text { The Mass } \\
\text { Ethanol } \\
(\text { grams })\end{array}$ & $\begin{array}{c}\text { Yield } \\
(\%)\end{array}$ \\
\hline 10 & 100 & 4 & 0.9910 & 32 & 31.7129 & 31.71 \\
\hline 12 & 120 & 8 & 0.9848 & 64 & 63.0259 & 52.52 \\
\hline 14 & 140 & 11 & 0.9805 & 88 & 86.2814 & 61.63 \\
\hline 16 & 160 & 10 & 0.9819 & 80 & 78.5496 & 49.09 \\
\hline 18 & 180 & 5 & 0.9894 & 40 & 39.5752 & 21.99 \\
\hline
\end{tabular}

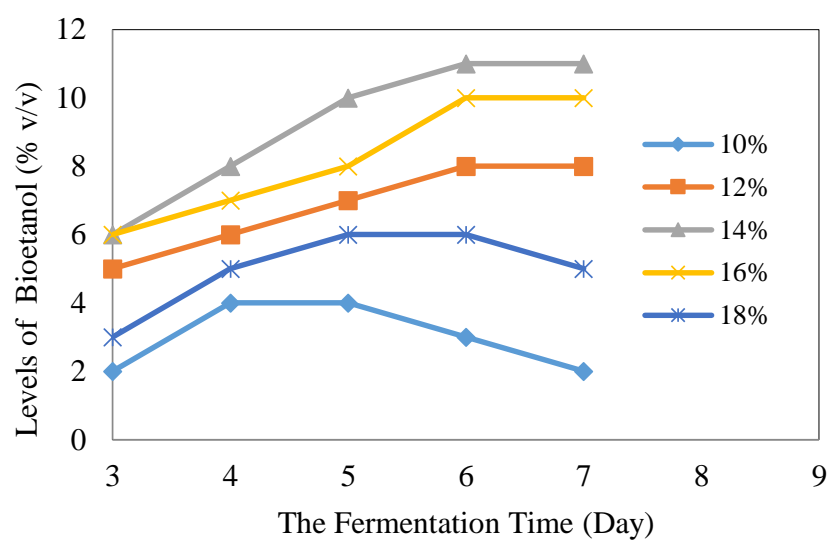

Fig. 2. The relationship between levels of bioetanol fermented with fermentation time

According to [14] initial substrate levels that are too high can reduce the amount of dissolved oxygen before the fermentation process takes place. Although in very small amounts, fixed oxygen needed by Saccharomyces cerevisae for microbial metabolic processes.

After the fermentation runs and obtained the best time to reach the highest levels of alcohol, alcohol that is produced will be stable for some time and then declined. This is because in the fermentation process of bacterial stationary phase and then experiencing a phase of death, but the time to reach the stationary phase is different on each treatment. On treatment with glucose $10 \%$ stationary phase occurred from day 4 to day 5 . On treatment with glucose $18 \%$ stationary phase occurred from day 5 to day 6 . This shows that using the initial glucose concentration is too high and too low can accelerate the time to reach the stationary phase. In contrast to the treatment that uses the initial glucose levels $12 \% ; 14 \%$; and $16 \%$ to reach the stationary phase on day 6 to 7 . Phase of death occurs on day 5 to day 7 for the initial $10 \%$ glucose levels, and on day 6 to day-7 initial glucose levels for $18 \%$. In the phase of death not all of the bacteria die. Some bacteria 
living oxidation alcohols so most alcohol formed is oxidized into pillars of compounds and carboxylic acids. So there happen levels decrease alcohol should do so the bacteria die warming.

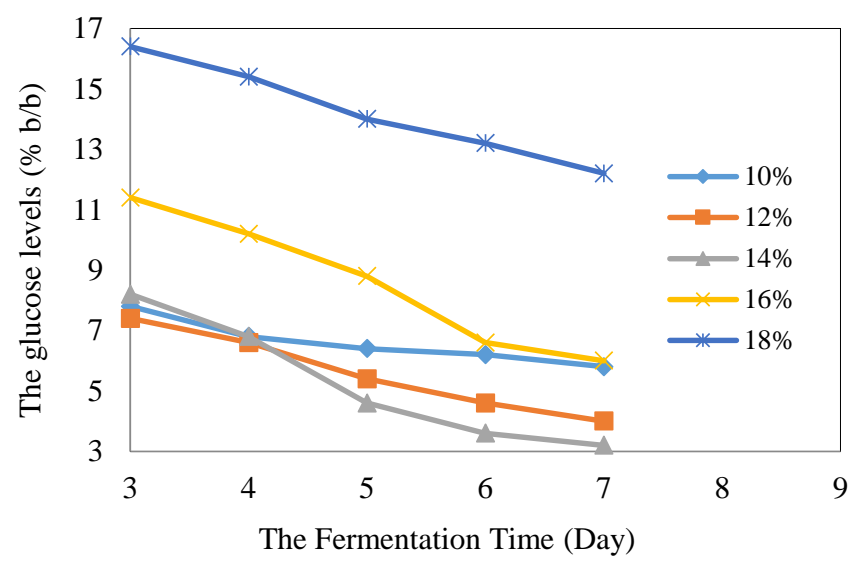

Fig. 3. The Relationship Between Levels Of Glucose Fermentation Time Remaining

Based on Figure 3 can note that the highest residual glucose levels found in the treatment using glucose levels beginning $18 \%$ and the lowest at the treatment by using the initial glucose levels $12 \%$. On treatment with initial glucose levels that are too high may cause glucose levels remaining high because it cannot be broken down completely by microbes. According to [1] on the influence of the addition of sugar in the manufacture of wine of Apple rejects, the greater the ratio of glucose at the start of the fermentation process caused a collision between molecules of the reactants with the microbes increases, so the intrusion of molecules microbes into the substrate, occur more frequently and cause glucose has not broken down completely. On treatment with glucose levels too low can also cause glucose remaining high enough, this is because the amount of food a little microbes that cause early reproductive cells of microbes that bit anyway so that glucose has not unraveled the perfect by microbes.

On treatment with the use of an initial $12 \%$ glucose can give a fairly high levels of ethanol and glucose levels remaining low due to satisfy food needs early so that microbes can reproduce well and glucose can be fermented into alcohol. Based on the overall data, residual levels of glucose results obtained at the end of fermentation can be aware that the remaining glucose levels obtained in accordance with the results of glucose that does not conversion to alcohols.

The best conditions of fermentation of glucose off grade by using fermiol the initial glucose levels take place at $16 \%$ and time best fermentation lasted 6 days produce ethanol levels of $10 \%(\mathrm{v} / \mathrm{v})$. This limits the use of Saccharomyces cerevisae because tolerance with the trade name fermiol which can produce alcohol with levels of more than $10 \%$ (v/v) than ordinary Saccharomyces Cerevisae will die when the resulting alcohol levels touching $10 \%(\mathrm{v} / \mathrm{v})$. Because fermiol is Saccharomyces Cerevisae modified by the factory so that it has the capability of generating levels of alcohol more than $10 \%(\mathrm{v} / \mathrm{v})$. However, the optimum levels of alcohol are produced in this research cannot be more than $10 \%(\mathrm{v} / \mathrm{v})$ due to fermiol being used has been saved long ago so that their effectiveness slightly reduced so that it can lower the levels of alcohol produced.

\section{CONCLUSION}

a. After dilution it is known that the content of glucose in glucose off grade raw materials amounting to $80 \%$, from the results of this process of dilution is done according the levels of variables being run, then fermented for 7 days using fermiol.

b. The best results on the fermentation of glucose levels at $14(\% \mathrm{v} / \mathrm{v})$ and lasted for 6 days that generate levels of bioethanol of $11(\% \mathrm{v} / \mathrm{v})$ with the highest percentage yield of $61.63 \%$.

c. The fermentation process takes place, obtained the smallest residual glucose levels $3.2 \%$ in treatment with the use of the initial glucose levels $14 \%$, while the largest remaining glucose levels $12.2 \%$ in treatment with the use of the initial glucose levels $18 \%$.

\section{ACKNOWLEDGMENT}

The authors would like to acknowledge the financial support of the Directorate Research and Public Service. The Directorate of Research and Development Strengthening. The Ministry of Research, Technology, and Higher Education of the Republic of Indonesia with the ResearchBased Competence Grant. Contract Number: 083/SP2H/LT/DRPM/2018.

\section{REFERENCES}

[1] Ariyanto, D. Hermawan, H. Furqon, and M. Joko, "Influence of The Addition of Sugar to Alcohol to Productivity in The Manufacture of Wine Made from Apple Waste (Rejects) Using Nopkor MZ," Journal of Chemical Technology and industry, vol. 2, pp. 226-232, 2013.

[2] Murtias, K. Dwi, A.H. Mulyati, and A. Budiyanto, Optimization of The Production of Liquid Sugar from Starch and Sago (Metroxylon spp.) The Origin of Southeast Sulawesi, Bogor: Chemical Studies Program University of Pakuan, 2015.

[3] The Central Bureau of Statistics, Statistics Indonesia Sugarcane 2013, Jakarta: Central Bureau of statistics, 2015, pp. 276-279.

[4] Martha, Belli, Yuwono, Felix, and T. Widjaja, Optimization of Fermentation Production of Ethanol from Molasses Borassus flabellifer Borassus flabellifer Using Microorganism Saccharomyces cerevisiae and Pichia stipitis with Response Surface Methods, Surabaya: ITS-Press, 2017, pp. 32-62.

[5] Rosyadi, A. Firda, Prasavitri, P. Kurnia, Widjaja, and Tri, "Optimization of Production Process of Ethanol Fermentation using The Technique of Molases-Extractive," POMITS Engineering Journal, vol. 3, pp. 135-136, 2013.

[6] Nuriana, Wahidin, and Wuryantoro, "Ethanol Synthesis from Jackfruit Stone Waste as Renewable Energy Source," Elsevier, vol. 65, pp. 372 377, 2014. 
[7] Sita, and T. Virginia, Optimization of Fermentation Process on A Production of Tuber Bioetanol Ube Microbe Saccharomyces cerevisiae Using. Makassar: final project report on the course of chemical engineering D3 State Polytechnic Ujung Pandang, 2016.

[8] K. Saravanakumar, P. Senthilraja, and K. Kathiresan, "Bioethanol Production by Mangrove-Derived Marine Yeast, Saccharomyces cerevisiae," Journal of King Saud University, vol. 25, pp. 121-127, 2012.

[9] Ernes, Atmiral, R. Lia, Wardani, K. Agustin, Kusnadi, Joni, “Optimasi Fermentasi Bagas Tebu oleh Zymomonas mobilis CP4 untuk Produksi Bioetanol," Agritech, vol. 34, pp.247-248, 2014.

[10] Figueroa, B. Juan, C.T. Arellano Julio, Gallegos, C.F. Adriana, Herera, R. Raul, Toledo, D. Heliodoro, N.A. Cristobal, "Native Yeasts for Alternative Utilization of Overripe Mango Pulp for Ethanol Production," Elsevier, vol. 226, pp.1-5, 2016.

[11] N.K. Sari, C. Pudjiastuti, and N. Abdi, Bioethanol Production Comparison of Elephant Grass and Liquid Waste Plant Wheat Boga Sari, Bandung: International Seminar on Biorenewable Resources Utilization for Energy and Chemicals, BE.02, 2013
[12] Muchtadi, and R. Tien, Food Processing Technology, Sheffield: Department for education and culture Directorate General of Higher Education Center Between food and nutrition University Institut Pertanian Bogor, 1997, pp. 126-129.

[13] Khak, Muhammad, and R.N. Rohmatningsih, "Optimization of Ethanol Production for Fermenters and Fermenting the Results Analysis Using Gas Chromatografi," Journal of Mathematics, Saint, and Technology, vol. 15(14), 2008.

[14] Elevri, P. Asga, and S.R. Putra, "Ethanol Production Using Saccharomyces cerevisiae Which Diamobilisasi with In Order for The Rod," Akta Kimindo, pp. 106, 2006.

[15] Otto, Eric, and J. Escovar-Kousen, "Ethanol Production by Simultaneous Saccharification and Fermentation (SSF)," United States Patent Application Publication, vol. 0026261, pp. A1p.7, 2005.

[16] Asli, and S. Maziar, "A Study on Some Efficient Parameters in Batch Fermentation of Ethanol Using Saccharomyces cerevesiae SC1 Extracted from Fermented Siahe Sardasht Pomace," Affrican Journal of Biotechnology, vol. 9, pp.2906-2912, 2010. 